\title{
Deterrence of Tippee Trading Under Rule 10b-5
}

One of the foremost problems in securities law today is the illegal practice of securities trading on the basis of undisclosed corporate information. Although efforts to curtail this practice have been directed primarily at transactions of insiders ${ }^{1}$ for their own accounts, ${ }^{2}$ the problem of tippee ${ }^{3}$ trading has received increased attention in recent years. ${ }^{4}$ The tippee trading problem is a variant of the insider trading situation. Rather than trading only for his own account, the insider communicates inside corporate data to others, not associated with the corporation, who trade on the inside information. The result is arguably the same: those with the information realize large profits at the expense of innocent third party traders.

It is now generally agreed ${ }^{5}$ that tippee trading, like insider trading on

1 An insider is one who, because of his position in or special relationship with the corporation, has access to corporate information likely to have definite effects on the price of the corporation's stock when it is made public.

2 See generally A. Bromberg, Securities LAws: Fraud-SEC Rule 10b-5 (1969); 3 \& 6 L. Loss, Securrties REgulation (1961); Fleischer, Securities Trading and Corporate Information Practices: The Implications of the Texas Gulf Sulphur Proceeding, 51 VA. L. REv. 1271 (1965).

3 Professor Loss coined this term to refer to a party who has no connection with a corporation but who receives material corporate information from an insider, referred to in this situation as a tipper, before the information is made public. $3 \mathrm{~L}$. Loss, SEcurrrIES REgULATION 1451 (1961).

4 See, e.g., Kuehnert v. Texstar Corp., 412 F.2d 700 (5th Cir. 1969); SEC v. Texas Gulf Sulphur Co., 258 F. Supp. 262 (S.D.N.Y. 1966), rev'd in part, 401 F.2d 833 (2d Cir. 1968), cert. denied, 394 U.S. 976 (1969), on remand, 312 F. Supp. 77 (S.D.N.Y. 1970); Investors Management Co., 1970 CCH FED. SEC. L. REP. I 77,832.

5 See cases cited note 4 supra. Cf. Investors Management Co., 1970 CCF FED. SEc. I. REP. I 77,844. Since § 10 (b) does not state specifically which parties are covered, it is arguable that its prohibition should be limited to insiders. Although $\S 15(\mathrm{~b})(3)$ of the bill reported to committee contained a provision applying the equivalent of the present $\$ 16$ to tippees, this provision was omitted from the bill reported by the committee due to feared administrative difficulties in applying it, rather than because tippee trading was condoned. Hearings on H.R. 7852 Before the House Comm. on Interstate and Foreign Commerce, $73 \mathrm{~d}$ Cong., 2d Sess. 9 (1934). See Fleischer, supra note 2, at 1283 n.64.

However, limiting the $10 \mathrm{~b}-5$ prohibition to insiders would exclude other parties privy to inside information and would, therefore, undermine the stated purposes of the Act. See text at notes 15-18. Moreover, the use of the words "any person" in § 10(b), as compared with specific designations of coverage in other sections of the Act, indicates that Congress intended a broad coverage. Compare $\$ 10(\mathrm{~b})$ 's use of "any person" with \$ 16, 15 U.S.C. \& 78p (1964) ("Directors, officers, and principal stockholders") and \& 8, 15 
undisclosed information, is prohibited by section $10(b)^{6}$ of the Securities Exchange Act of $1934^{7}$ and by the corresponding SEC rule 10b-5. ${ }^{8}$ Tippee trading is more difficult to curtail than insider trading, however, for it involves such added complexities as identifying the trader as a tippee and locating the source of the tip. Once these facts are established, there remain the problems of allocating the civil liability, if any, between the tipper and the tippee, and of determining at what "level"10 tippee trading will cease to be a violation. However, neither Congress in passing the Act, nor the SEC in formulating the rule, provided adequate guidelines to resolve these complexities. As a result, in spite of the apparent clarity of the goals of the legislation,,$^{11}$ neither the courts ${ }^{12}$ nor the SEG ${ }^{13}$ has maintained a consistent policy regarding tippee violations.

This comment focuses on the tippee trading aspect of insider abuse. It examines the pertinent provisions of the 1934 Securities Exchange

U.S.C. \$ 78h (1964) (“members, brokers and dealers"). See also \$ 9, 15 U.S.C. § $78 \mathrm{i}$ (1964). There a careful distinction is made between the words "dealer or broker" and "any person," indicating a much broader meaning for "any person."

6 15 U.S.C. $\$ 78 \mathrm{j}$ (1964). The section provides:

It shall be unlawful for any person, directly or indirectly, by the use of any means or instrumentality of interstate commerce or of the mails, or of any facility of any national securities exchange-

....

(b) To use or employ, in connection with the purchase or sale of any security registered on a national securities exchange or any security not so registered, any manipulative or deceptive device or contrivance in contravention of such rules and regulations as the Commission may prescribe as necessary or appropriate in the public interest or for the protection of investors. [Emphasis added.]

715 U.S.C. $\$ \S 78$ a et seq. (1964).

817 C.F.R. \& 240.10b-5 (1970). The rule provides:

It shall be unlawful for any person, directly or indirectly, by the use of any means or instrumentality of interstate commerce, or of the mails or of any facility of any national securities exchange,

(a) To employ any device, scheme, or artifice to defraud,

(b) To make any untrue statement of a material fact or to omit to state a material fact necessary in order to make the statements made, in the light of the circumstances under which they were made, not misleading, or

(c) To engage in any act, practice, or course of business which operates or would operate as a fraud or deceit upon any person,

in connection with the purchase or sale of any security.

8 "I recognize that [the tippee] may be difficult to trace so that his potential liability is not the best of restraints. But to strengthen the restraint against him by insulating from responsibility the insider-tipster seems to me precisely the wrong way effectually to restrain tips from circulating." Kuehnert v. Texstar Corp., 412 F.2d 700, 706 (5th Cir. 1969) (Godbold, J., dissenting).

10 The tippee who receives his information from the insider is the first level tippee. If he further communicates the information, the recipient is referred to as a second level tippee and similarly to the successive levels to which the information passes. The term "tippee" will be used herein to refer to one of the first level unless otherwise indicated. Problems may arise in defining "tippee" and in determining the "level of tippee;" these problems, however, are beyond the purview of this comment.

11 See text at notes 15-18 infra.

12 Judicial treatment of the tipping problem is discussed below in Part IIB.

13 See text at notes $38-51$ infra. 
Act and the judicial and SEC responses to these provisions, and proposes a judicial solution to the problem of tippee trading. ${ }^{14}$

14 The prerequisites of materiality, reliance, and purchase and sale are demanded in all suits based on the use of inside information and thus there must be some preliminary mention of these issues before solutions to the tipping problem can be discussed. Since the goal of the 1934 Act surely cannot be the furthering of unfounded speculation in the market, without the use of any information, there must be some way in which to distinguish the forbidden information from the information which a party is allowed to use. The forbidden information is referred to as "material information" and a finding of materiality is essential to establish a violation of $\S 10(b)$. In Texas Gulf Sulphur the court reaffirmed the definition of "materiality" that it had originally formulated in List v. Fashion Park, Inc., 340 F.2d 457 (2d Cir.), cert. denied, 382 U.S. 811, rehearing denied, 382 U.S. 933 (1965):

The basic test of materiality . . . is whether a reasonable man would attach importance [to the omitted or misrepresented fact] ... in determining his choice of action in the transaction in question .... This, of course, encompasses any fact "... which in reasonable and objective contemplation might affect the value of the corporation's stock or securities ....."

401 F.2d at 849. The court went on to elaborate on the List test by stating:

In each case, then, whether facts are material within Rule 10b-5 when the facts relate to a particular event and are undisclosed by those persons who are knowledgeable thereof will depend at any given time upon a balancing of both the indicated probability that the event will occur and the anticipated magnitude of the event in light of the totality of the company activity.

$I d$. Because the determination of materiality is so peculiarly related to the individual fact situation, it encounters many of the same ambiguities which the reasonable man standard has encountered in general tort law. As in tort law, the individual acts at his own peril and consequently, if the sanctions are extreme enough, this ambiguity may have the undesired result of deterring parties from trading at all because of fear of the risk of trading on inside information.

Closely related to the issue of materiality in $10 \mathrm{~b}-5$ claims is the required element of reliance. Again in List the court fashioned what has been accepted in such later cases as Texas Gulf Sulphur to be the test of reliance. The court stated: "The proper test is whether the plaintiff would have been influenced to act differently than he did act if the defendant had disclosed to him the undisclosed fact." List v. Fashion Park, Inc., 340 F.2d 457, 463 (2d Cir. 1965). The court in List stated that not to require the element of reliance would be to establish a scheme of investors' insurance. Yet as litigation involving multiple parties and the anonymity of the stock market is brought under $10 \mathrm{~b}-5$, the issue of reliance is likely to be replaced by the sole requirement of materiality. The time and difficulty in proving individual reliance would be too great a burden for each individual plaintiff. See Kahan v. Rosenstiel, 424 F.2d 161, 173.74 (3d Cir.), cert. denied, 398 U.S. 950 (1970). The movement from requiring reliance to requiring only materiality would not appear to be too great a change, for, as the court noted in List, the difference between materiality and reliance is that the former employs the reasonable man test while the latter looks to the particular plaintiff. Compare Mills v. Electric Auto-Lite Co., 396 U.S. 375 (1970), holding that defects in proxy statements are material per se, and that no reliance on them need be proven.

The final element in a $10 \mathrm{~b}-5$ action is the purchase and sale requirement. $\S 10(\mathrm{~b})$ explicitly states that actionable fraud is "in connection with the purchase or sale of any security." 15 U.S.C. § 78j(b) (1964). See Birnbaum v. Newport Steel Corp., 193 F.2d 461 (2d Cir.), cert. denied, 343 U.S. 956 (1952); Herpich v. Wallace, 430 F.2d 792 (5th Cir. 1970); Rekant v. Desser, 425 F.2d 872, 877 (5th Cir. 1970). Therefore, no party can file an action if his only complaint is that had he known the undisclosed information he would have either bought or sold. A party is injured only if he did in fact buy or sell. 


\section{Section 10(b) in the Tippee Context}

The Securities Exchange Act of 1934 and the Securities Act of the previous year ${ }^{15}$ were designed to bring order to a chaotic securities market by prohibiting many of the practices which had characterized the securities exchanges during the previous decade. ${ }^{16}$ An important goal of the Act, embodied in section 10(b), was to equalize investors' positions in the securities markets by equalizing access to relevant corporate information. This purpose was summarized in the committee report accompanying the bill:

In order that parties may trade [in the stock market] on even terms, they should have, as far as is practicable, the same opportunities for knowledge in regard to the subject matter of the trade. ${ }^{17}$

Congressman Maloney, the floor manager of the bill, stated that section 10(b) "gives the man on the outside a knowledge up to now reserved to himself by the man on the inside."18

Although this goal might be achieved by requiring complete disclosure of all material corporate information, the courts and the SEC have consistently rejected this approach in favor of a prohibition of trading on the basis of such information. A person in possession of undisclosed information ${ }^{19}$ either must disclose or refrain from trading -if he trades he may be held liable for any damages caused to innocent third party traders. ${ }^{20}$ Thus, a scheme designed to effectuate the goals of the Act must serve two purposes: 1) it must, in the first instance, deter tippee trading; and 2) where such deterrence fails, it must provide for restitution to the injured third parties. These purposes may be achieved by either or both of two available methods: criminal punishment and civil liability.

15 I5 U.S.C. \$§ 77a et seq. (1964).

16 See generally J.K. Galbratth, The Great Crash, 1929 (1955).

17 H.R. REP. No. 1383, 73d Cong,, 2d Sess. 12 (1934). See also id. at 11, 13.

1878 CoNG. REg. 7869 (1934). See also id. at 7717 (remarks of Congressman Ford), 7862 (remarks of Congressman Lea), and 7864 (remarks of Congressman Wolverton).

19 "Thus, anyone in possession of material inside information must either disclose it to the investing public, or, if . . . he chooses not to do so, must abstain from trading ...." SEC v. Texas Gulf Sulphur Co., 401 F.2d 833, 848 (2d Cir. 1968). "If, on the other hand, disclosure prior to effecting a purchase or sale would be improper or unrealistic under the circumstances, we believe the alternative is to forego the transaction." Cady, Roberts \& Co., 40 S.E.C. 907, 911 (1961). "It would appear to be the position of the Commission that rule $10 \mathrm{~b}-5$ does not compel the disclosure of corporate information if there have been no securities transactions." Fleischer, supra note 2, at 1295.

20 The utility of prohibiting trading on inside information to enforce $\S 10(\mathrm{~b})$ is somewhat questionable. Even in the area of insider trading, where there is a limited universe of 


\section{A. Criminal Punishment}

Section 32(a) of the 1934 Securities Exchange Act prescribes fines, imprisonment or both for violation of any provision of the Act by any person. $^{21}$ However, a scheme placing primary reliance on criminal sanctions to deter tippee trading is unlikely to be successful. First, the maximum fine under $32(a)$ is only $\$ 10,000$. While such a penalty might deter some tips, it is insufficient to curtail the most serious violations, which often involve profits far in excess of the maximum fine. ${ }^{22}$

Second, section 32(a) allows ignorance of the law as a defense to the imprisonment sanction..$^{23}$ Since tippees, as opposed to insiders, are often somewhat unsophisticated investors, this defense would create large gaps in the enforcement process. ${ }^{24}$ Finally, as in other areas of whitecollar crime, the courts have been extremely reluctant to impose the criminal penalties-section 32 has been cited in only seven cases and only once with regard to insider trading. ${ }^{25}$ Given these considerations,

violators, detection is at best sporadic. A prohibition on tippee trading is even more difficult to enforce, for the universe of potential tippees is virtually unlimited and detection is likely to occur only in the most obvious of cases. However, short of radical reorganization of the market structure, the only presently available means to prevent tippee trading is to attempt to enforce the $10(\mathrm{~b})$ proscription. This comment proceeds upon this basic assumption.

21 \& 32(a), 15 U.S.C. \& 78ff(a) (1964), provides:

Any person who willfully violates any provision of this chapter, or any rule or regulation thereunder the violation of which is made unlawful or the observance of which is required under the terms of this chapter, ... shall upon conviction be fined not more than $\$ 10,000$, or imprisoned not more than two years, or both ... ; but no person shall be subject to imprisonment under this section for the violation of any rule or regulation if he proves that he had no knowledge of such rule or regulation. [Emphasis added.]

22 The $\$ 10,000$ fine may be sufficient to deter the tipper if he is receiving no economic benefit for the tip. See text and note at note 34 infra.

23 See note 21 supra.

24 This is not necessarily a weakness for it can be argued that only those who know that their actions are illegal can be deterred. It is a weakness only if it is assumed that there is a class of persons able to be deterred who cannot be punished because of the ignorance defense. The "no-knowledge" section appears to have been construed by only one court, United States v. Lilley, 291 F. Supp. 989 (S.D. Tex. 1968), and many questions concerning the defense remain unanswered. The Lilley court stated in regard to the question:

Proof of no knowledge cannot mean proof that defendants did not know, for example, the precise number or common name of the rule, the book and page where it was to be found, or the date upon which it was promulgated. It does not even mean proof of a lack of knowledge that their conduct was proscribed by rule rather than by statute. Proof of "no knowledge" of the rule can only mean proof of an ignorance of the substance of the rule, proof that they did not know that their conduct was contrary to law.

Id. at 993.

25 United States v. Minuse, 142 F.2d 388, 389 (2d Cir. 1944) (wash sales and dummy accounts); Bank of America Nat'l Trust \& Savings Ass'n v. Douglas, 105 F.2d 100, 103 (D.C. Cir. 1939) (registration of a security); United States v. Mandel, 296 F. Supp. 1038, 1039 (S.D.N.Y. 1969) (short sale); United States v. Saporta, 270 F. Supp. 183, 186 (E.D.N.Y. 1967) (unlawful pledge of stock); United States v. Guterma, 189 F. Supp. 265 (S.D.N.Y. 1960) 
and in view of the failure of criminal sanctions to compensate injured third parties, an effective deterrent scheme cannot rest solely on the threat of criminal sanctions. ${ }^{26}$

\section{B. Civil Liability and Damages}

For these reasons, any effective solution to the tippee trading problem must be based primarily on civil liability. Utilization of civil liability to deter tippee trading raises two complex problems: (1) determining the extent of liability, and (2) allocating this liability among the "guilty" parties.

1. Extent of Liability. An exact determination of damages caused by tippee trading is made impossible by the complex nature of the market structure. For example, tippee purchases may drive up the price of the stock, and this may in turn attract new investors or cause existing investors to sell. But the extent of these effects is both unpredictable and immeasurable. Thus, it is necessary to establish some method to approximate damages.

Such an approximation may be achieved in either of two ways: (1) damages may be viewed as including total profits that all innocent sellers would have made had they held their stock until the inside information was finally disclosed, or (2) damages may consist only of total profits realized by the tippee between the day of purchase and the day of disclosure. Although the former approach would seem desirable in that it compensates all third parties, the latter more closely approximates the actual damages caused by the illegal trading.

Analysis may be facilitated by analogizing the market transaction to a private transaction where there are no undeterminable market effects. Consider, for example, the first purchase by a defendant in $S E C$ v. Texas Gulf Sulphur Co. of 300 shares on November 12, 1963 at $\$ 18$ per share. ${ }^{27}$ In a private sale, the seller's damages presumably would be measured by the amount he lost by selling-rather than holding-the stock. Since he would not have sold had he known the undisclosed information, and since he is free to repurchase the stock upon effective disclosure, ${ }^{28}$ his loss consists of the difference in price between the date

(Failure to file statements with SEC); United States v. Pope, 189 F. Supp. 12, 21-23 (S.D.N.Y. 1960) (registration and proxy statements). Only in United States v. Lilley, 291 F. Supp. 989 (S.D. Tex. 1968), did the court cite § 32 in reference to a violation of rule 10b-5.

28 When the element of criminal sanctions is introduced, the fifth amendment right against self-incrimination may come into play. To find a violation, it is often necessary to rely on testimony of the parties involved, yet this is often either practically or constitutionally impossible. Thus, only if there exists independent evidence of a violation can criminal sanctions be applied.

27401 F.2d at 840 n.2 (the purchase of defendant Fogarty).

28 The "effective disclosure" date is used rather than the disclosure date to allow the injured plaintiff time to assimilate and react to the disclosure. 401 F.2d at 858-54 n.18. 
of sale and the date of effective disclosure. Assuming the price of the stock is $\$ 41$ when disclosure becomes effective, ${ }^{29}$ the seller's total loss would be $\$ 6,900$. This would approximate total damages in the actual market transaction, subject of course to incidental effects of the illegal purchase.

This examination of the private transaction situation demonstrates that the second of the two approaches suggested above is preferable. Under the first method, the tippee would be liable to all parties who sold Texas Gulf Sulphur stock between the date of illegal transaction and the date of effective disclosure. Since approximately three million shares of the stock were sold in that period ${ }^{30}$ at an average price of $\$ 25$ per share, ${ }^{31}$ the tippee's total liability would be $\$ 45$ million. Such a result bears no rational relation to the $\$ 6,900$ estimate obtained earlier. Moreover, under this approach the total liability is independent of the number of shares purchased by the tippee. The total liability is $\$ 45$ million regardless of whether the tippee purchased one share and made a $\$ 23$ profit or purchased 10,000 shares and made a quarter of a million dollars. Finally, although the potential for such extensive liability might create a significant deterrent effect, to be meaningful the punishment must bear some reasonable relation to the reprehensibility of the illegal conduct. $^{32}$

The second measure of liability, the total profits of the tippee, would produce a damage figure of $\$ 6,900$. Like the $\$ 6,900$ damages suffered by the seller in the hypothetical private transaction, this method ignores the indirect market effects of tippee trading and so errs to that extent. It does, however, produce a liability that is reasonably related to the number of shares purchased by the tippee, and it realistically approximates the damages actually caused. ${ }^{33}$

29 In Texas Gulf Sulphur the price used was $\$ 40$ 3/8. 312 F. Supp. at 93.

30 See Ruder, Texas Gulf Sulphur-The Second Round: Privity and State of Mind in Rule 10b-5 Purchase and Sale Cases, 63 Nw. U.L. REv. 423, 429 n.37 (1969).

31 The $\$ 25$ sales price is an assumption as the real average sales price would depend upon the price received for each of the 3 million shares. Considering that the November 12 th price was $\$ 18$, did not reach $\$ 25$ until March 26 th, and was below $\$ 30$ until April 16th, this estimate may overstate the average price received by third parties and therefore understate the $\$ 45$ million amount of liability. 401 F.2d at 840 n.2.

32 See generally Andenaes, The Morality of Deterrence, 37 U. CHI. L. REv. 649 (1970).

33 The latitude available in determining the "effective disclosure" date would allow courts to adjust the damages to the equities of the case. In SEC v. Texas Gulf Sulphur Co., 312 F. Supp. 77, 93 (S.D.N.Y. 1970), the court determined that the day after disclosure was the appropriate date and that the average price on that date was the appropriate price. This produced the figure of $\$ 6,900$ in the hypothetical case. In Reynolds v. Texas Gulf Sulphur Co., 309 F. Supp. 548, 565 (D. Utah 1970), the court ruled that one day was an inadequate length of time to allow the plaintiffs to react, so it measured damages from 
2. Allocation of Liability. Since both the tippee and the tipper have violated $10(\mathrm{~b})$, either or both may be held liable. To fulfill the goals behind the 1934 Act effectively, however, liability should be imposed where it will achieve its maximum deterrent force-upon the tipper. If the tipper is deterred the problem is ended and there is no need to deter the tippee. Moreover, the tipper is less likely than the tippee to risk liability, since unlike illegal transactions for his own account, he is unlikely to benefit personally from the tipping violation..$^{34}$ The threat of liability for profits realized by others with no economic gain for himself ought to deter most potential tippers.

Tippee liability, however, is not likely to deter tippee trading. If the only liability of the tippee is to make restitution of his illegal gains, there would be in fact no deterrent effect. If the violations were discovered and the tippee were required to give up all of his gains, he would remain in the same position as before the transaction. However, if not apprehended, he would retain substantial profits. Thus, he could only gain by using the inside information. ${ }^{35}$

Moreover, the tipper may be the only party to have knowledge of the prohibition on tippee trading. A corporate officer would presumably be aware of the proscription, whereas the tippee, frequently a relative or non-business friend of the tipper, might not even be aware that the conduct is prohibited. ${ }^{36}$ Thus, as a practical matter, most tippees could not be deterred. ${ }^{37}$

A sound tipper-tippee policy therefore requires that deterrent measures be focused primarily on the tipper. Unfortunately, neither the SEC nor the judiciary has thus far developed a solution that both deters tipping and provides for restitution.

the average of the daily highs for the next twenty trading days. This would have increased the damages to $\$ 10,000$ in the hypothetical case. In contrast, the use of the time of disclosure would reduce damages to $\$ 3,900$.

34 It is possible that rather than giving a tip as a purely personal act, the tipper might sell or trade it. However, this would not lessen the effect of measures intended to deter the tipper. Even if the tipper has an opportunity to sell the tip, he will be less likely to do so if he is threatened with total liability for the resulting damages.

35 This ignores any stigma that might attach to being forced to make restitution. That this stigma would be insignificant is suggested by the fact that it would be a non-criminal white collar transgression.

36 "Insiders are relatively a smaller group, and by their positions more likely to know or to be advised by counsel of the allowable limits on their conduct." Kuehnert v. Texstar Corp., 412 F.2d 700, 706 (5th Cir. 1969) (dissenting opinion).

37 "The relatively larger class of tippees are persons less likely to know of the prohibitions on insider information. The tippee may be no more than the unsophisticated odd-lot purchaser who is told by his broker over the telephone of 'confidential' data on the company and buys a few shares of listed stock relying thereon." Id. 


\section{Attempts to Implement Section 10(b)}

\section{A. SEC Policies}

The first step taken by the SEC to implement section $10(\mathrm{~b})$ was the promulgation of rule $10 \mathrm{~b}-5,{ }^{38}$ which followed closely the wording of the Act. ${ }^{30}$ The Commission adopted a narrow reading of the rule, stating that it did not apply to tippees unless the tippee acted "in [concert] with or conspiracy with" a tipper. ${ }^{40}$ This approach, had it been retained, not only would have exempted a large class-tippees-from the $10 \mathrm{~b}-5$ proscription, but would have provided a means by which the rules against insider trading could be easily circumvented. Rather than trade on inside information themselves, insiders could exchange tips, thereby insulating themselves from the prohibition.

The initial approach of the SEC was rejected in Cady, Roberts of Co. ${ }^{41}$ In that case, an employee of Cady, Roberts, a brokerage firm, who served also as a director of Curtiss-Wright Corporation, informed Gintel, a partner in Cady, Roberts, of an undisclosed cut in CurtissWright's dividend. Gintel then sold Curtiss-Wright stock owned both by himself and by various Cady, Roberts clients before the dividend cut was announced. As a result, Gintel was suspended from trading for twenty days. While the case is important in that it established tippee trading as a violation, it did nothing to compensate those injured by the illegal transaction. Such a solution, which leaves the tipper undeterred

38 The policy underlying the rule was stated by the SEC as follows:

The Securities and Exchange Commission today announced the adoption of a rule prohibiting fraud by any person in connection with the purchase of securities. The previously existing rules against fraud in the purchase of securities applied only to brokers and dealers. The new rule closes a loophole in the protections against fraud administered by the Commission by prohibiting individuals or companies from buying securities if they engage in fraud in their purchase.

Securities Exchange Act of 1934, Release No. 3230 (May 21, 1942).

39 See notes 6 \& 8 supra.

40 [An] insider could communicate to an outsider the same information he knows, and the outsider might act on it, and unless the Commission had evidence from which they could conclude that the insider was a party in fact to the transaction, either acted in concern [sic] with or conspiracy with the outsider, I do not think that they would hold the outsider as being in violation of rule $\mathrm{x}-10 \mathrm{~b}-5 \ldots$.

Hearings before a Subcomm. of the House Comm. on Interstate and Foreign Commerce, 82d Cong., 2d Sess. 726 (1952) (statement of Mr. Byrne, Regional Administrator, SEC, New York City).

1140 S.E.C. 907 (1961). The Securities and Exchange Commission, referring to rule 10b-5 stated: "These anti-fraud provisions are not intended as a specification of particular acts or practices which constitute fraud, but rather are designed to encompass the infinite variety of devices by which undue advantage may be taken of investors and others." Id. at 911 . Referring to actions by others than insiders, the Commission stated that the rule and section "apply to securities transactions by 'any person.' Misrepresentations will lie within their ambit, no matter who the speaker may be." Id. 
and the injured parties without compensation, fails to fulfill the purpose of the Act.

In SEC v. Golconda Mining Co., ${ }^{42}$ the SEC took a somewhat different approach even though the factual situation was similar. Magnuson, a director of Hecla Mining Company, learned of an undisclosed pending merger which would be very favorable to Hecla. He, and Golconda Mining, his tippee, both traded on the basis of the information. The SEC sued the tippee, Golconda, for restitution of the profits. ${ }^{43}$ Although such a suit may compensate injured parties, it does not provide a satisfactory deterrent since no attempt is made to deter the tipper-the party most vulnerable to deterrent pressure.

The next important SEG action, the filing of suit in SEC v. Texas Gulf Sulphur Co., ${ }^{44}$ involved a series of transactions in Texas Gulf Sulphur stock by several officers and employees of that company who traded on the basis of major undisclosed mineral discoveries in Canada. In addition, two of the insiders passed this information to friends, who also purchased stock. Abandoning its earlier approaches, the SEC sued the tippers for restitution of their respective tippees' profits. While this approach is consistent with one primary goal of the Act-deterrence of tippers-it raises the possibility that the tipper might not have adequate funds to compensate the injured parties. ${ }^{45}$ Although this problem did not arise in Texas Gulf Sulphur, the approach of suing only the tipper might well sacrifice the second goal of restitution.

Merrill Lynch, Pierce, Fenner \& Smith ${ }^{48}$ and Investors Management Co. ${ }^{47}$ were the next tipper cases brought by the SEC. Merrill Lynch, while gathering information necessary to underwrite Douglas Aircraft bonds, learned of a sharp decline in Douglas' earnings. This information was passed on to a number of Merrill Lynch's institutional customers, who sold Douglas stock before the earnings decline was publicly announced. As a result, both the tipper, Merrill Lynch, and the tippees were reprimanded.48 Although ostensibly deterring both

$121970 \mathrm{CCH}$ FED. SEC. L. REP. I 92,504 (S.D.N.Y. 1969).

43 Magnuson was sued for restitution of his own profits but not for those realized by Golconda. Id. at 98,357 .

44258 F. Supp. 262 (S.D.N.Y. 1966).

45 See text at note 70 infra.

401968 CCH FED. SEC. L. REP. If 77,629.

$471970 \mathrm{CCH}$ FED. SEC. L. REP. I7,832. (The Commission on its own initiative directed review of the initial decision. 1970 CCH FED. SEC. L. REP. I 77,844. The review decision has not yet been handed down.)

48 As to Merrill Lynch, the SEC ordered that its New York Institutional Sales Office and West Coast Underwriting Office be suspended for 21 and 15 days respectively; it also censured an industry specialist and dissociated him without compensation for 60 days; it censured five salesmen and an office manager and dissociated them without compensation for 21 days; and censured two vice-presidents and one office manager. 1968 CCH FED. SEC. 
tipper and tippee, the actual deterrent effect of such action is slight. Since the tippees realized approximately $\$ 11 / 2$ million $^{49}$ as a result of the tips, the failure to seek restitution is remarkable. Although Merrill Lynch was severely reprimanded, ${ }^{\text {to }}$ the tippees, the real beneficiaries, received only nominal punishment. ${ }^{\text {st }}$ Thus, neither deterrence nor restitution was achieved.

\section{B. Judicial Policies}

The courts also have recognized the equalization-of-information purpose of rule $10 \mathrm{~b}-5,{ }^{52}$ but have not been any more successful in devising a viable, consistent remedy. In two cases, Myzel v. Fields ${ }^{53}$ and Ross v. Licht $^{, 54}$ the courts held tippers and their tippees jointly and severally liable. Although this approach apparently was adopted primarily because the tippers and tippees were in an agency-like relation, ${ }^{55}$ it does have certain advantages which may be generalized to all tipping situations. Injured parties are protected because their claims can be met out of the resources of both the tipper and tippee, and, since both parties are potentially liable, there is a significant deterrent effect. However, as noted earlier, ${ }^{56}$ the threat of liability is not effective against the tippee, since, even if detected, he loses only his profits. Thus, to the extent that the injured party satisfies his judgment claim against the tippee-who is not deterred-the deterrence against the tipper-who can be deterredis reduced.

In Texas Gulf Sulphur the courts held the tippers liable for the profits of their tippees, but not for the profits of second level tippees. ${ }^{5 \pi}$

L. REP. If 77,629 , at 83,351 . In contrast to these actions, the SEC merely censured the twelve tippees guilty of trading on the Merrill Lynch tip. Investors Management Co., 1970 CCH FED. SEC. L. REP. If 77,832, at 83,962.

49 The tippees received approximately $\$ 13.4$ million for the shares that they traded. Had they sold them at the highest price received after Douglas had announced the earnings decline, they would have received only $\$ 11.9$ million. $I d$. at $83,930,83,938$.

50 See note 48 supra.

61 Id.

52 "The core of Rule $10 \mathrm{~b}-5$ is the implementation of the Congressional purpose that all investors should have equal access to the rewards of participation in securities transactions." SEC v. Texas Gulf Sulphur Co., 401 F.2d 833, 851-52 (2d Cir. 1968).

53386 F.2d 718 (8th Cir. 1967), cert. denied, 390 U.S. 951 (1968).

54263 F. Supp. 395 (S.D.N.Y. 1967).

55 The facts of the two cases were very similar; in both the tippees bought the interests of minority stockholders in closely held corporations and then resold the stock to their tippers, the controlling stockholders.

56 See text at notes 34-36 supra.

57 The court stated: '[W]ith respect to Darke's 'tippees,' a distinction will be made between those who purchased TGS securities on Darke's recommendation and those who purchased on the recommendation of one of Darke's "tippees." "It concluded: "[1]t will be a sufficient deterrent if Darke is directed to pay to TGS the profits realized by the 'tippees' who purchased on [his] recommendation ..." \$12 F. Supp. at 95. 
The only possible explanation for cutting off liability at the first level, absent a finding of non-materiality, is some notion of fairness, perhaps that the tipper has been punished sufficiently. ${ }^{58}$ Certainly the injury to the public is the same whether the tippee is first or second level..$^{50}$ To ignore second level tippee activity quite conceivably would result in the practice of passing the information twice before trading on it, thus insuring against liability.

The next tippee case, SEC $v$. Golconda Mining Co., ${ }^{60}$ was settled by a court-approved stipulation requiring the tippee to pay his profits into a damage fund. Rather than dividing the damages among all those who sold Hecla stock during the period Golconda was trading on inside information, the court appointed a trustee to determine the identities of the particular sellers from whom Golconda purchased the stock. Thus, not only does this approach involve the disadvantages of tippee liability, but it institutes a purely fortuitous method of determining which injured parties are to be compensated.

An unusual tipper-tippee situation, one with no injured third parties, existed in Kuehnert $v$. Texstar Corp. ${ }^{61}$ The president of Texstar knowingly gave Kuehnert false "tips." On the basis of these "tips" Kuehnert traded in Texstar stock and suffered substantial losses. He brought a $10 \mathrm{~b}-5$ suit against his informant and Texstar alleging misrepresentation of material facts. The case was dismissed on the grounds that Kuehnert had been in pari delicto with his tipper-that he had been attempting to trade on inside information and therefore was violating rule $10 \mathrm{~b}-5$ himself. Read broadly in the context of normal tipper suits-involving injured third parties-this approach might be interpreted as holding that the court will place liability on whichever party the injured third party sues. Such an approach ignores the significant advantages in deterrence that result from suing the tipper. ${ }^{62}$

$58 I d$.

59 Respondents further claim that the insider's duty of disclosure should not be imposed upon them because they were neither insiders nor "even the immediate 'tippees' of such insiders." They argue that such remoteness creates critical practical problems that make the application of the disclosure rule extremely unfair to them. In particular they cite problems in determining whether information is coming from an insider and whether it is still non-public. They refer also to problems which beset a tippee in attempting to disclose insider information and in deciding when to act on the information received.

While agreeing that tippees may be faced with difficulties in resolving the problems raised by respondents, no perceptible reason appears for accepting such problems as a predicate for a blanket exemption from the disclosure requirement. Even less persuasive are respondents' arguments when viewed in connection with situations where persons such as respondents, highly sophisticated in financial matters, are the tippees.

Investors Management Co., 1970 CCH FED. SEC. L. REP. I 77,832, at 83,940.

601970 CCH FED. SEC. L. REP. I 92,504 (S.D.N.Y. 1969).

61412 F.2d 700 (5th Cir. 1969).

62 See also Wohl v. Blair \& Co., 50 F.R.D. 89 (S.D.N.Y. 1970). 


\section{A Proposed Judicial Solution}

Neither the SEC nor the judiciary has thus far developed a consistent, viable means of dealing effectively with the tipping situation. The present, apparently ad hoc, approach should be replaced by a single, all-encompassing solution aimed at achieving the twin goals of deterrence and restitution.

Since deterrence is the most effective means of eliminating the evils of tippee trading, and since the tipper is the party against whom deterrent measures are most effective, ${ }^{83}$ the courts should, as a first step in each case, hold the tipper liable for the full amount of his tippee's profits. ${ }^{64}$

In addition to the recent $10 \mathrm{~b}-5$ cases, there is precedent from other areas of the law for holding the tipper liable for injury caused by those who acted on his information. In Mosser $v$. Darrow, ${ }^{65}$ a bankruptcy case, employees of the reorganization trustee profited by trading in the debtor's stock. After this activity was discovered, the original trustee was discharged and his successor brought suit against the first trustee for his employees' profits. The theory of this suit was that the first trustee had breached the fiduciary obligations of his position. As with the tipper, the trustees had realized no profits from his employees' activities. ${ }^{66}$ The trustee was surcharged for the amount of his employees' profits because he had committed the more serious offense of violating the trust of his position. ${ }^{67}$ Such is, of course, the essence of the insider's wrongdoing when he becomes a tipper.

One result of placing full liability on the tipper, particularly if such liability extends to profits of second level tippees, is the creation of a potentially huge liability. However, as in the field of torts, where men are held liable for the consequences of their acts without regard to their proportions, this fact should not militate against use of the remedy. Moreover, this may be the very fact that makes the deterrence effective.

63 See text at notes 33-35 supra.

64 If the SEC adopts such a solution, there is the issue of whether it has then usurped a legislative function, since Congress has clearly provided for punitive remedies in the 1934 Act to cover violations. Such an argument would seem to be moot, as courts since Kardon v. National Gypsum Co., 73 F. Supp. 798 (E.D. Pa. 1947), have consistently recognized a private cause of action under the 1934 Act. This indicates that the remedies provided within the Act have not been interpreted as the exclusive sanctions. See cases cited in Astor v. Texas Gulf Sulphur Co., 306 F. Supp. 1333, 1340 (S.D.N.X. 1969).

65341 U.S. 267 (1951).

66 Id. at 268.

67 See the holding in Berner v. Equitable Office Bldg. Corp., 175 F.2d 218 (2d Cir. 1949), in which the attorney for the shareholders of a reorganization bankrupt leaked information that affected the price of the bankrupt's stock. See also the discussion in Cady, Roberts \& Co., 40 S.E.C. 907, 919-14 (1961). 
Another possible shortcoming of such a scheme is that the tippee remains in possession of the profits resulting from the violation. A system which leaves untouched one "as equally reprehensible"68 as the instigator of the illegal scheme seems somewhere to have failed. Since punitive damages cannot be awarded under the Act, ${ }^{69}$ total damages cannot be greater than profits. Therefore, holding the tippee liable for damages necessarily reduces the amount of tipper liability and consequently reduces the deterrent effect. However, it does not seem sensible to abandon totally attempts to deter the tippee. Furthermore, if no attempt is made to curb the activity of tippees, they have no reason not to become tippers themselves and convey the inside information to second level tippees-thus compounding the harm done by the original violation.

Even though deterrence is aimed primarily at the tipper, some measures should be directed at the tippees to deter them from using inside information. Moreover, since it cannot be assumed that all corporate insiders are persons of extensive means, exclusive tipper liability might well result in an inadequate damage fund from which to provide restitution to injured third parties. ${ }^{70}$ To avoid these difficulties, the tippee should be held secondarily liable as a guarantor, to the extent of his profits, of any judgment which the tipper cannot satisfy.71 Thus, a system of "hierarchical liability" is created.72 The tippee-

08 Referring to the tippees the court in Texas Gulf Sulphur stated: "As Darke's tippees are not defendants in this action, we need not decide whether . . . their conduct is as equally violative of the Rule as the conduct of their inside source, though we note that it certainly could be equally reprehensible." $401 \mathrm{~F} .2 \mathrm{~d}$ at $852-53$.

60 See Globus v. Law Research Serv., Inc., 418 F.2d 1276, 1283 (2d Cir. 1969).

70 In related areas under the 1933 Act, it has been stated that deterrence, rather than compensation, is the primary goal. See id. at 1288.

71 As a general rule, when a void is left in a federal statute, the courts will fill it by reference to the common law. The courts could proceed here by analogy to several common law doctrines such as the ancient doctrine of contribution, see generally W. Prosser, LAw of TORTs $\S 47$ (3d ed. 1964); conspiracy, $i d$. at $\S 43$; or the joint tortfeasor rule, $i d$. at ch. 8.

72 It is conceivable that a situation could arise in which the tipper would not know that the information he relayed to the tippee was, in fact, material inside information. For example, in Cady, Roberts, Cowdin believed that the news of the dividend reduction had already gone out on the ticker. When he called Gintel and relayed this information to him, Cowdin did not realize that the secretary had erred while typing the release and consequently that public dissemination of the fact had been delayed. In such a situation the liability should still be placed on the tipper for two reasons. First, despite his state of mind, there are still injured third parties. Secondly, the tipper is forced, under this scheme, to be extremely careful whenever he gives advice in regard to stock trading. For the same reasons tippees in such a situation also should be subject to the same liability as they would be under the hierarchical liability scheme despite the fact that they did not know that they were trading on material inside information. $C f$. Investors Management Co., $1970 \mathrm{CCH}$ FED. SEC. L. REP. If 77,832, at 83,940. 
guarantor, who is likely to have retained some, if not all, of his illegal profits, assures third parties of a source for damage payments. Such a scheme does not dilute the deterrent effect against the tipper, since the tippee is held liable only if the judgment against the tipper remains unsatisfied due to the tipper's insolvency or unavailability. ${ }^{73}$

The tippee may be deterred also with regard to the profits of second level tippees. Although second level tipping is a proximate result of the original tip, it is the direct result of the first level tippee's activity. In this relation to the second level tippees, the initial tippee is the tipper and should be primarily liable for the injury resulting from second level trading. ${ }^{74}$ A similar approach should be adopted at each level to which the tip is passed. Placing this liability on the initial tippees should insure that they will not further disseminate the information and will thus reduce the harm to the public. Further, this method may deprive the first level tippee of part or all of his gain. In the event that the initial tippee cannot make restitution for all the gains of his tippees, the second level tippees should be liable for their own profits. And, if neither the initial tippee nor the second level tippees can make restitution, the initial tipper should be held liable as a guarantor for the profits of the second level tippees. ${ }^{75}$

A final question to consider in implementing this scheme involves the possibility of suits between the tipper and tippees. As has been stressed throughout this comment, deterrence is best achieved by placing primary liability on the tipper. ${ }^{76}$ Under the hierarchical liability scheme, at least whenever there are injured third parties, liability must

73 A tipper is "unavailable" when the court can obtain neither in rem nor in personam jurisdiction over him. But, so as not to multiply the number of suits based on this one cause of action, the third party should be required to show due diligence in his attempt to locate the tipper.

74 Thus the same duties of disclosure are imposed on "outside" tippees as on "inside" tippers. Compare Cady, Roberts \& Co., 40 S.E.C. 907, 912 (1961), with Mills v. Sanjem Corp., 133 F. Supp. 753, 764 (D.N.J. 1955).

75 Despite the past reluctance of the courts to impose the criminal provisions of § 32(a) (see text and note at note 26 supra), the hierarchical liability scheme should not be seen as foreclosing the possibility of using the criminal or administrative sanction upon the tipper or subsequent tippees if it is felt that the situation was such a gross violation as to demand sanctions other than economic ones. However, it should be noted that under the 1934 Act punitive damages cannot be awarded to a third party. See Globus v. Law Research Serv., Inc., 418 F.2d 1276, 1283 (2d Cir. 1969). Broker-dealers may be more affected by the use or threatened use of criminal or administrative sanctions: "And there always lurks the psychological deterrent of being branded a knowing violator of the law. This is particularly true in an industry [underwriting] where, as the sages put it, a good name is worth more than a crown." Id. at 1285. For a discussion of the applicability of administrative remedies to tippers and tippees, regardless of whether they are brokerdealers, see Investors Management Co., 1970 CCH FED. SEC. L. REP. If 77,832, at 83,931.

7o See text at notes 34-37 supra. 
remain on the tipper and the courts should refuse to allow any suit by the tipper against the tippee for contribution, ${ }^{77}$ since such a suit would dilute the deterrent effect of the scheme. This denial of contribution should be based not on the doctrine of in pari delicto, but rather on the need to maintain a consistent deterrent policy under the scheme. Moreover, the doctrines of in pari delicto and contribution require some subjective standard of "badness" to trigger the lossspreading device, and such a standard "makes it almost impossible to create an orderly and consistent body of law. . .."78

If a third party sues the tippee, rather than the tipper, the court should allow the tippee to implead the tipper. ${ }^{79}$ Not only does impleading allow the court to find tipper liability, but it also brings both the guarantor and the tipper before the court. Consequently, the compensation fund, whether it be created solely from the tipper's pocket or with the aid of the guarantors, can be established in one proceeding. Finally, if the tipper is found by the court to be unavailable, ${ }^{80}$ the court should allow the tippee to be sued and then give the tippee the right to proceed against the tipper should he later become available.

Kuehnert $v$. Texstar Corp. ${ }^{81}$ presents a difficult problem in the application of the hierarchical solution. Where the tip is false and only the tippee is injured, the doctrine of in pari delicto should be applied to preclude tipper liability. Although at first glance this may seem inconsistent with the proposed scheme, it serves the ends of justice without weakening the deterrent effectiveness of the scheme. If the tipper believes the information to be true, he will be deterred by the hierarchical liability without regard to whether the information is in reality false. Thus, tipper liability is not essential for deterrence reasons. On the other hand, if the tippee is allowed to sue the tipper in such a situation, total deterrence against the tippee is reduced. Prohibiting the tippee to

$7 \pi$ This solution is just the opposite of the outcome of the litigation that began in Mosser v. Darrow, 341 U.S. 267 (1951). In Darrow v. Kulp, 220 F.2d 495 (7th Cir. 1955), a suit by the trustee subsequent to the Supreme Court's decision, the court refused to dismiss the trustee's complaint which sought recovery from the employees based on a theory of equitable subrogation. This type of approach concentrates the deterrence upon the tippee, and as shown above at notes 34-36, this is not the most effective way of stopping the tipping process. See also Globus v. Law Research Serv., Inc., 418 F.2d 1276 (2d Cir. 1969), where contribution also was allowed. It should be noted that contribution under $\S 10(b)$ is in some cases a judicially created right and thus in those cases can be judicially denied. deHass v. Empire Petroleum Co., 286 F. Supp. 809, 815-16 (D. Colo. 1968).

78 Kuehnert v. Texstar Corp., 412 F.2d 700, 706 n.3 (5th Cir. 1969).

79 See FED. R. Crv. P. 14(a).

80 See note 73 supra.

81412 F.2d 700 (5th Cir. 1969). See text a. note 61 supra. 
sue forces him to accept the risk of a bad tip. Where the tipper knows the tip to be false, the loss should once again fall on the tippee, since this is not a true tipping situation and the doctrine of in pari delicto should be applied as a matter of course. ${ }^{82}$

82 See 50 B.U.L. REv. 87 (1970). 